\title{
Humectants as Post-plant Soil Amendments: Effects on Growth and Physiological Activity of Drought-stressed, Container-grown Tree Seedlings
}

\author{
Bruce R. Roberts, R. Scott Linder, Charles R. Krause, and Ryan Harmanis
}

\begin{abstract}
One-year-old seedlings of red maple (Acer rubrum L.) and yellow poplar (Liriodendron tulipifera L.) were treated with Hydretain ES ${ }^{\text {TM }}$ (HydES) or EcoSential ${ }^{\text {TM }}(\mathrm{EcoS})$ applied as a soil drench. A progressive drought cycle was imposed after treatment, and as each seedling wilted, the leaves and roots were harvested. Foliar growth was unaffected by HydES or EcoS, but root growth (roots $<1 \mathrm{~mm}$ diameter) was significantly less for seedlings grown in the humectant-treated media. These data, along with measurements of substrate moisture content taken during a similar dry down period, suggest that droughtinduced fine root growth in humectant-treated media was slower because there was less need for these roots to extend and proliferate in search of additional soil moisture supplies. In studies conducted the following year, HydES or EcoS were applied as a soil drench to one-year-old seedlings of red maple and river birch (Betula nigra L.) prior to withholding irrigation. In these studies, measurements of chlorophyll fluorescence, leaf gas exchange, and xylem water potential indicate that physiological activity was greater for drought-stressed seedlings grown in HydES-treated media compared to similar seedlings grown in EcoS-treated media, a condition attributed to lower levels of plant-water stress (higher xylem water potentials) in the HydES-treated seedlings.

Key Words. Acer rubrum; Betula nigra; Chlorophyll Fluorescence; $\mathrm{CO}_{2}$ Exchange; Liriodendron tulipifera; Organic Amendments; Production Type; Red Maple; River Birch; Root Zone Moisture Management; Yellow Poplar.
\end{abstract}

While transplant success and tree establishment depend on the successful completion of a chain of events ranging from propagation to aftercare (Struve 2009), reduced post-plant growth is primarily the result of plant water stress caused by root loss at harvest (Hasse and Rose 1993). It is widely recognized that adequate moisture is an important factor affecting the physiological well-being of trees in the urban environment (Wiseman 2004), and transplants often undergo massive physiological shock because of disruptions in the soil-plant-air continuum that occur during transplanting (Kramer and Boyer 1995). Since substantial portions of the root system may be removed during harvest, the presence of sufficient functional root tissue and the existence of adequate soil moisture resources are critical factors in the successful post-plant establishment of newly planted trees (Watson and Himelick 1997).

To help ameliorate the effects of transplant shock and to stimulate post-plant growth and development, numerous nontraditional soil additives have been studied as possible backfill amendments. These additives have met only limited success, partly because they don't adequately address the problem of root zone soil moisture management (Abbey and Rathier 2005). More recent technology has resulted in the development of certain organic substances, including polyhydric alcohols, such as glycerol and sorbitol, which function as humectants. Humectants are hygroscopic substances containing several hydrophilic groups, often hydroxyl groups, which have a strong affinity to form hydrogen bonds with water molecules. Aqueous solutions of these organic compounds have specific humidity equilibrium points that inhibit evaporation to, and absorb moisture from, the atmosphere at relative humidities above their equilibrium point (Hanson 1999). Thus, when applied to the growing media around plant material, humectants have the potential to enhance the proportion of water available for plant growth by extracting moisture from air spaces within the soil matrix and in certain instances, by inhibiting the evaporative loss of water from porous soils.

While humectant-containing compounds have gained widespread acceptance in pharmaceutical, food, and personal care products, their use in agriculture is less well documented. A review of existing literature suggests that the primary use of humectants in agriculture has been as carriers for water-soluble herbicides (Matsumoto et al. 1992; Marzouk et al. 1998; Ramsey et al. 2005; Ramsey et al. 2006). Proprietary products containing humectants have also been used to improve the drought resistance of bedding plants (Barrett 1991) and to increase the yield of tomato plants (Ciardi et al. 1998). With the exception of an agricultural extension report from Clemson University (Arena 2001), in which the stem caliber of Hydretain ${ }^{\mathrm{TM}}$-treated and untreated live oaks was compared, no scientific studies could be found that involve the use of humectant-containing compounds for improving the drought tolerance of woody plants.

The present investigation is the continuation of an earlier study (Roberts and Linder 2010), which was undertaken to determine if commercially available humectant products might 
extend the irrigation cycle of newly planted tree seedlings. The authors of the current study wanted to ascertain whether humectants have an impact on subsequent growth and/or physiological activity of treated plant material, thereby determining their potential usefulness as amendments for improving transplant success and establishment for recently transplanted woody plants. The studies reported here were conducted in a greenhouse over a two-year period using plant material grown in a commercially available soilless substrate in order to eliminate some of the environmental variables that often confound results obtained in field trials. Seedlings were used to provide more consistent and uniform plant material and, as such, represent an important first step in evaluating the effectiveness of humectant treatment using larger plant material under field conditions.

\section{METHODS AND MATERIALS}

\section{Growth Measurements (2008 Trials)}

In mid-February 2008, one-year-old seedlings of both Jiffy Plug ${ }^{\mathrm{TM}}$ and bare root red maple (Acer rubrum L.) and one-year-old bare root seedlings of yellow poplar (Liriodendron tulipifera $\mathrm{L}$.) were purchased from a commercial nursery. Both the Jiffy Plug (seeded and grown in peat plugs) and bare root (seeded and grown in mineral soil) seedlings were transplanted into $3.8 \mathrm{~L}$ plastic pots containing a soilless substrate consisting of composted pine bark, coconut pith coir, sphagnum peat moss, processed bark ash and perlite (Metromix 560; Sun Gro Horticulture, Vancouver, British Columbia, Canada). The chemical and physical properties of this substrate have been reported elsewhere (Roberts 2006). At transplant, root systems of the Jiffy Plug red maples were left intact (unpruned), while the bare root seedlings, both red maple and yellow poplar, were pruned back $25 \%-35 \%$ to facilitate placement in the planting container. To distinguish between these two production methods, the authors will hereafter refer to the plug-grown, non-root-pruned seedlings as PPS (peat plug seedlings), and the soil-grown, root-pruned seedlings as BRS (bare root seedlings).

Transplanted seedlings of both species and both production types were placed in a greenhouse $\left(18^{\circ}-26^{\circ} \mathrm{C} ; 60 \%+/-12 \%\right.$ relative humidity) and exposed to 10 hours of light $\left[80-120 \mathrm{~W} / \mathrm{m}^{2}\right.$ photosynthetically active radiation (PAR; natural day length plus supplemental illumination from $175 \mathrm{~W}$ metal halide lamps on a two-hour photoperiod)]. The seedlings were hand-watered as needed to maintain media moisture content at or near container capacity. Following bud break, and one week prior to the start of the experiment, all seedlings were fertilized with Osmocote Plus 15-912 controlled release fertilizer ( $15 \mathrm{~g} / \mathrm{pot})$ and Micromax granular micronutrient fertilizer ( $2.5 \mathrm{~g} / \mathrm{pot})$, both applied as a top dressing (Scotts-Sierra Horticultural Products Co., Marysville, Ohio, U.S.)

Treatment consisted of a single root-drench application of either Hydretain ES $^{\mathrm{TM}}$ (HydES), a liquid organic product containing $58 \%$ humectants, $1.3 \%$ non-ionic surfactant, and $40.7 \%$ inert ingredients (Ecologel Solutions LLC, Ocala, Florida, U.S.), or EcoSential $^{\mathrm{TM}}($ EcoS), a similar product containing 50\% humectants, $15 \%$ non-ionic surfactant, and 35\% inert ingredients (LESCO, Inc., Cleveland, Ohio, U.S.). Seven seedlings of each species (red maple, yellow poplar) and each production type (PPS, BRS) were assigned to one of the following five treatment groups: 1) water (control); 2) HydES applied at the manufacturer's recommended rate (16 mL/L); 3) HydES at $12 \mathrm{~mL} / \mathrm{L}$; 4) EcoS applied at the manufacturer's recommended rate $(16 \mathrm{~mL} / \mathrm{L}) ; 5) \mathrm{EcoS}$ at 12 $\mathrm{mL} / \mathrm{L}$. To assure uniformity in seedling size between treatments, growth index (GI) measurements (average of seedling height and two-dimensional crown width; Monterusso et al. 2005) were used in assigning seedlings to each treatment group. The volume of liquid $(350 \mathrm{~mL})$ applied to each pot was sufficient to thoroughly saturate the growing medium without causing substantial runoff; however, a plastic tray ( $15 \mathrm{~cm}$ diameter) was placed beneath each container to collect any excess liquid and to allow for re-absorption.

After treatment, seedlings were randomly arranged on a greenhouse bench and, starting the following day, a progressive drought cycle was imposed by withholding water. When each seedling wilted (visual observation) it was harvested and the following determinations made: height; canopy size; number of leaves; leaf area; leaf dry weight; length and surface area of roots $<1 \mathrm{~mm}$ and $>5 \mathrm{~mm}$ diameter; and root dry weight. [NOTE: on average, untreated seedlings wilted (and were subsequently sampled) about one week earlier than humectant-treated seedlings.] Leaf area measurements were made with a LI-3100C area meter (LI-COR, Lincoln, Nebraska, U.S.). Root morphological data (length and surface area) were determined using the WinRHIZO image analysis system (Regent Instruments, Inc., SteFoy, Quebec, Canada). Biomass measurements were recorded after oven drying tissue at $70^{\circ} \mathrm{C}$ for 48 hours. From the raw data collected, the following growth indices were calculated: growth index, specific leaf area, leaf area index, specific root length, fine root:coarse root ratio, and root area index. In a companion experiment, data were collected on changes in substrate moisture content (SMC) of unplanted Metromix 560 subjected to a drought period lasting four weeks. In this experiment, SMC was sampled at three fixed locations in each of 12 pots (six HydES-treated; six untreated) using a moisture meter and matrix sensor (Delta-T Devices, Ltd., Cambridge, UK). Gravimetric measurements of substrate evaporative water loss per unit surface area (evaporative index, EI) were also recorded daily.

\section{Physiological Measurements (2009 Trials)}

In early February 2009, one-year-old PPS and BRS seedlings of red maple and river birch (Betula nigra L.) were purchased from two commercial nurseries. The seedlings were transplanted into 3.8 L plastic pots containing a soilless substrate (Metromix 560) and were placed in a greenhouse under the conditions previously described. After six weeks, all seedlings except the PPS birch had broken dormancy. (NOTE: It was subsequently discovered that the root systems of many PPS birch had frozen during shipment and an insufficient number of plants were available to include in this study). After the remaining seedlings (BRS birch; PPS and BRS maple) had reached full leaf, and about one week before starting the study, they were top-dressed with controlled release and granular micronutrient fertilizers as previously described.

The 2009 treatments consisted of a single root-drench application $(350 \mathrm{~mL})$ of either water (control) or humectant (HydES or EcoS at a concentration of $16 \mathrm{~mL} / \mathrm{L}$ ) applied to seedlings with a similar range of GI values. After treatment, seedlings were randomly arranged on a greenhouse bench and drought-stressed by withholding water. As drought progressed, seedlings were sampled in groups of three based on the appearance of foliar wilt symptoms in each untreated (control) plant. Thus, each time a droughted, untreated seedling showed wilt 
symptoms, it was sampled along with a droughted, HydEStreated and a droughted, EcoS-treated seedling (all three with the same rep number). At sampling, in situ chlorophyll fluorescence and leaf gas exchange measurements were taken on one young, fully expanded leaf from each seedling using the leaf plastochron index (Larson and Isebrands 1971) as the criterion for selecting leaves with comparable morphological traits.

Chlorophyll fluorescence was measured at room temperature $\left(22^{\circ} \mathrm{C}\right)$ on the adaxial leaf surface using a pulse-modulated fluorometer (FMS-2; Hansatech Instruments Ltd., King's Lynn, UK). Each leaf was dark-adapted prior to measuring initial, maximum, and variable fluorescence. Following the dark period, light-adapted fluorescence readings (steady-state and maximum fluorescence) were taken on the same leaf. From these data, the maximum efficiency and quantum yield of photosystem II were calculated (Maxwell and Johnson 2000). After measuring chlorophyll fluorescence, leaf gas exchange measurements were made on the same seedling using a portable leaf chamber analyzer (LCA-4; Analytical Development Co., Hertfordshire, UK). Net photosynthesis $(\mathrm{Pn})$, transpiration (Ts), and stomatal resistance $\left(r_{s}\right)$ were measured at a light intensity of $650 \mu \mathrm{moles} / \mathrm{m}^{2} / \mathrm{s}$ PAR using a single leaf positioned either directly opposite (maple), or opposite and immediately below (birch) the leaf used to measure fluorescence. Gas exchange measurements (five consecutive five-minute readings) were initiated after $\mathrm{CO}_{2}$ levels in the enclosed leaf chamber reached $400-425 \mathrm{ppm}$. After measuring leaf gas exchange, each seedling was destructively harvested, and xylem water potential determinations were made on the terminal $15 \mathrm{~cm}$ shoot section using a Scholander pressure chamber (SoilMoisture Equipment Corp., Santa Barbara, California, U.S.).

\section{Data Analyses}

Data for both the growth (2008) and physiological (2009) studies were analyzed as randomized complete block designs using an analysis of variance (ANOVA). Since there was only one production type each for yellow poplar (2008 study) and river birch (2009 study), the designs were unbalanced, meaning that statistical analyses involving more complex interactions were not possible. Models for both designs were fit and analyzed using statistical software (Minitab). Differences in treatment means were compared using Tukey's pairwise comparison test at significance levels of 0.05 and 0.01 . Because there were no significant differences between the two humectant levels used in 2008 (12 and 16 $\mathrm{mL} / \mathrm{L}$ ), the growth data reported here reflect only results obtained with the $16 \mathrm{~mL} / \mathrm{L}$ concentration since this allowed comparisons to be made with the physiological data collected in 2009 , in which only one concentration $(16 \mathrm{~mL} / \mathrm{L})$ of each humectant was used.

\section{RESULTS AND DISCUSSION}

\section{Foliar Growth}

There was no significant effect of humectant treatment on foliar growth of droughted red maple or yellow poplar seedlings in the 2008 experiments (only GI data shown), nor was there any significant difference between the two humectant products tested (HydES and EcoS) (Table 1).

\section{Root Growth}

For PPS red maples, fine root growth [root length $(\mathrm{RL}<1)$ and root surface area $(\mathrm{RSA}<1)$ of roots $<1 \mathrm{~mm}$ diameter] was significantly greater for seedlings grown in untreated (control) substrate than for similar seedlings grown in either HydES- or EcoS-treated substrate (Table 1). These differences are reflected in the calculation of fine root:coarse root ratio $(\mathrm{F}: \mathrm{C})$ and root area index $(\mathrm{RAI})$, both of which were significantly greater for PPS maples grown in the untreated substrate (Table 1). While the pattern of fine root growth for BRS maples was similar to that for PPS maples (i.e., greater fine root growth in untreated substrate), the differences were not statistically significant (Table 1). No significant differences in root growth were found for yellow poplar seedlings grown in either humectant-treated or untreated (control) substrate (Table 1).

Table 1. Growth of one-year-old, drought-stressed tree seedlings treated with Hydretain ES (HydES) and EcoSential (EcoS).

\begin{tabular}{|c|c|c|c|c|c|c|c|c|}
\hline Species & $\begin{array}{l}\text { Production } \\
\text { type }^{y}\end{array}$ & Humectant & $\mathrm{GI}^{\mathrm{x}}$ & $\begin{array}{l}\mathrm{RL}<1^{\mathrm{w}} \\
(\mathrm{cm})\end{array}$ & $\begin{array}{l}\mathrm{RSA}<1^{\mathrm{v}} \\
\left(\mathrm{cm}^{2}\right)\end{array}$ & $\begin{array}{l}\mathrm{RL}>5^{\mathrm{u}} \\
(\mathrm{cm})\end{array}$ & $\mathrm{F}: \mathrm{C}^{\mathrm{t}}$ & $\mathrm{RAI}^{\mathrm{s}}$ \\
\hline \multirow{5}{*}{$\begin{array}{l}\text { Red } \\
\text { maple }\end{array}$} & \multirow{2}{*}{ PPS } & 0 (control) & $21.6 \mathrm{~ns}$ & 1831a & $161 \mathrm{a}$ & $30 \mathrm{~ns}$ & $60.3 \mathrm{a}$ & $2.06 \mathrm{a}$ \\
\hline & & HydES & 18.3 & $944 b$ & $83 b$ & 27 & $35.1 \mathrm{~b}$ & $1.32 \mathrm{~b}$ \\
\hline & \multirow[t]{3}{*}{ BRS } & 0 (control) & $29.7 \mathrm{~ns}$ & 2074 ns & $227 \mathrm{~ns}$ & $38 \mathrm{~ns}$ & $55.6 \mathrm{~ns}$ & $3.20 \mathrm{~ns}$ \\
\hline & & HydES & 29.0 & 1590 & 188 & 39 & 41.1 & 2.84 \\
\hline & & EcoS & 29.1 & 1793 & 212 & 35 & 51.6 & 2.96 \\
\hline \multirow{2}{*}{$\begin{array}{l}\text { Yellow } \\
\text { poplar }\end{array}$} & \multirow[t]{2}{*}{ BRS } & 0 (control) & $26.3 \mathrm{~ns}$ & $632 \mathrm{~ns}$ & $87 \mathrm{~ns}$ & $42 \mathrm{~ns}$ & $15.1 \mathrm{~ns}$ & $2.11 \mathrm{~ns}$ \\
\hline & & EcoS & 24.6 & 393 & 39 & 40 & 9.5 & 1.57 \\
\hline
\end{tabular}

${ }^{2}$ Seedlings grown in a greenhouse in $3.8 \mathrm{~L}$ plastic pots filled with soilless substrate (Metromix 560) and treated with $12 \mathrm{or} 16 \mathrm{~mL} / \mathrm{L}$ of HydES or EcoS prior to withholding water. Since no significant differences in growth were noted between the two concentrations used in these studies, only data from the $16 \mathrm{~mL} / \mathrm{L}$ treatment are included here. Each value represents the mean of seven replications. For each species and production type, values in the same column differ significantly when followed by a different letter, Tukey $0.05 ; \mathrm{ns}=$ no significant differences.

${ }^{y}$ Peat plug-grown (PPS) seedlings; bare root-grown (BRS) seedlings.

${ }^{x}$ Growth index (height + two-dimensional crown width / 3).

w Length of roots $<1 \mathrm{~mm}$ diameter.

${ }^{v}$ Surface area of roots $<1 \mathrm{~mm}$ diameter.

"Length of roots $>5 \mathrm{~mm}$ diameter.

${ }^{\mathrm{t}}$ Fine root:coarse root ratio.

${ }^{\mathrm{s}}$ Root area index (root surface area/substrate surface area). 
The observation that fine root growth of PPS maples in droughted, untreated media exceeded that for similar maples in droughted, humectant-treated media was unexpected. However, since SMC was always lower and EI initially higher in droughted, untreated substrate than in droughted, HydES-treated substrate (Table 2), and since root elongation in mildly-stressed plants often exceeds that in more well-watered plants (Jupp and Newman 1987; Sharp and Davies 1979), it is possible that fine root growth in the drier untreated substrate was greater because roots in this media continued to grow in order to access needed sources of soil moisture. This same line of reasoning may account for why there were no significant differences in coarse root growth (roots $>5 \mathrm{~mm}$ diameter) between seedlings of either species (red maple or yellow poplar) or between seedlings grown in either substrate (untreated or humectant-treated) (Table 1), since larger diameter roots, which normally become suberized and lignified, are less likely to be involved in water absorption (Kramer and Boyer 1995).

In comparing root growth between the two species used in the 2008 trials (red maple and yellow poplar), it was found that RSA $<1, F$ :C, and RAI were significantly greater for humectant-treated maples (both HydES- and EcoS-treated) than for humectant-treated poplars (Table 3; $P<0.01$ ), data which may reflect differences in root growth between fine-rooted (red maple) and coarse-rooted (yellow poplar) species. In comparing root growth between the two production methods used in these studies (PPS and BRS maples), the study authors also observed that RSA $<1$ and RAI were significantly greater $(P<0.01)$ for humectant-treated BRS maples than they were for similarly treated PPS maples (Table 3).
In earlier studies, Arena (2001) reported finding an increase in caliper growth of Hydretain ${ }^{\mathrm{TM}}$-treated live oak, and Ciardi et al. (1998) described an increase in fruit yield of Hydretain-treated tomato. Results of the current investigations suggest that although humectants do not effect top growth, they may indirectly impact root growth in drought-stressed soils by providing more readily available soil moisture, thereby reducing the need for the fine roots of humectant-treated seedlings to grow in search of additional moisture resources (Roberts and Linder 2010).

\section{Chlorophyll Fluorescence}

Measurements of chlorophyll fluorescence are frequently used to assess the overall efficiency of a plant's photosynthetic apparatus, especially photosystem II (PSII) (Maxwell and Johnson 2000). Since, in practical terms, measurements of the ratio of variable to maximum fluorescence $(\mathrm{Fv} / \mathrm{Fm})$ provide information on the maximum efficiency of PSII (Sagaram and Burns 2009), fluorescence data collected in the present study suggest that energy transformations in PSII were significantly lower for PPS maples grown in EcoS-treated substrate than they were for similar maples grown in either untreated or HydES-treated substrate (Table 4). The fact that quantum efficiency of EcoStreated maples was appreciably lower than for HydES-treated maples is particularly interesting given that both humectants contain the same active ingredients. However, while the active ingredients are the same, the surfactant concentration of EcoS $(15 \%)$ is more than $10 \times$ that found in HydES $(1.3 \%)$, and high

Table 2. The effect of drought on substrate moisture content (SMC) and evaporative water loss (evaporative index (EI)) of humectant-treated and untreated Metromix $560^{z}$.

\begin{tabular}{|c|c|c|c|c|c|c|}
\hline \multirow[t]{2}{*}{$\begin{array}{l}\text { No. of weeks } \\
\text { without water }\end{array}$} & \multicolumn{3}{|c|}{$\begin{array}{c}\mathrm{SMC}^{\mathrm{y}} \\
\text { (percent saturation) }\end{array}$} & \multicolumn{3}{|c|}{$\begin{array}{c}\mathrm{EI}^{\mathrm{x}} \\
\left(\mathrm{g} / \mathrm{cm}^{2}\right)\end{array}$} \\
\hline & $\begin{array}{l}\text { Humectant } \\
\text { treated substrate }(\mathrm{H})\end{array}$ & $\begin{array}{l}\text { Untreated substrate } \\
\text { (U) }\end{array}$ & $\mathrm{U} / \mathrm{H}$ & $\begin{array}{l}\text { Humectant treated } \\
\text { substrate }(\mathrm{H})\end{array}$ & $\begin{array}{l}\text { Untreated } \\
\text { substrate }(\mathrm{U})\end{array}$ & $\mathrm{U} / \mathrm{H}$ \\
\hline$\overline{0}$ & 47.1 & 47.1 & 1.00 & 0.75 & 0.75 & 1.00 \\
\hline 1 & 28.2 & 26.8 & 0.95 & 0.59 & 0.65 & 1.10 \\
\hline 2 & 18.3 & 16.3 & 0.89 & 0.21 & 0.22 & 1.05 \\
\hline 3 & 10.8 & 8.9 & 0.82 & 0.09 & 0.09 & 1.00 \\
\hline 4 & 7.4 & 6.2 & 0.84 & 0.04 & 0.04 & 1.00 \\
\hline
\end{tabular}

${ }^{\mathrm{z}}$ Equal quantities of substrate placed in $3.8 \mathrm{~L}$ plastic pots and treated with $350 \mathrm{~mL}$ of Hydretain ES prior to withholding water. Each value represents the mean of six replications.

${ }^{y}$ Measured at three fixed locations in each of 12 pots (six treated; six untreated).

${ }^{x}$ Weight loss/substrate surface area.

Table 3. Table of P-values comparing root growth and physiological activity of one-year-old, drought stressed tree seedlings treated with Hydretain ES (HydES) and EcoSential (EcoS) 2 .

\begin{tabular}{|c|c|c|c|c|c|c|c|}
\hline \multirow[t]{2}{*}{ Comparison } & \multirow[t]{2}{*}{ Humectant } & \multicolumn{3}{|c|}{ Root growth (2008) } & \multicolumn{3}{|c|}{ Physiological activity (2009) } \\
\hline & & $\mathrm{RSA}<1^{\mathrm{y}}$ & $F: C^{x}$ & $\mathrm{RAI}^{\mathrm{w}}$ & $\mathrm{Fv} / \mathrm{Fm}^{v}$ & $\mathrm{Pn}^{\mathrm{u}}$ & $\mathrm{XWP}^{\mathrm{t}}$ \\
\hline \multirow[t]{2}{*}{ Species $^{\mathrm{s}}$} & HydES & $<0.01 * *$ & $<0.01 * *$ & $0.01 * *$ & 0.99 & 0.30 & 0.26 \\
\hline & EcoS & $<0.01 * *$ & $<0.01 * *$ & $<0.01 * *$ & 0.30 & 0.93 & 0.12 \\
\hline \multirow[t]{2}{*}{ Prod typer } & HydES & $<0.01 * *$ & 0.32 & $<0.01 * *$ & 0.16 & 0.12 & 0.06 \\
\hline & EcoS & $<0.01 * *$ & 0.09 & $<0.01 * *$ & 0.14 & 0.47 & 0.60 \\
\hline
\end{tabular}

${ }^{\mathrm{z}}$ Seedlings grown in $3.8 \mathrm{~L}$ plastic pots filled with soilless substrate (Metromix 560) and treated with $16 \mathrm{~mL} / \mathrm{L}$ of HydES or EcoS prior to withholding water. Root growth of each seedling measured at incipient wilt. Physiological activity measured for groups of three seedlings (one each untreated; HydES-treated; EcoS-treated) at the time each untreated seedling reached incipient wilt. Comparisons made using Tukey's pairwise comparison test, $P<0.05(*), P<0.01(* *)$.

y Surface area of roots $<1 \mathrm{~mm}$ diameter.

${ }^{x}$ Fine root:coarse root ratio.

${ }^{\text {w }}$ Root area index (root surface area/substrate surface area).

${ }^{v}$ Variable/maximum fluorescence (max efficiency of PSII photochemistry).

"Photosynthetic rate.

${ }^{\mathrm{t}}$ Xylem water potential.

s Maple (BRS) versus poplar (BRS) in 2008; maple (BRS) versus birch (BRS) in 2009.

${ }^{\mathrm{r}}$ PPS (maple) versus BRS (maple) in 2008 and 2009. 
surfactant concentrations have been shown to compromise the biophysical integrity of PSII membranes and to modify the kinetics of chlorophyll fluorescence (Ruan et al. 2002). Thus, EcoS treatment could potentially impact chlorophyll fluorescence, assuming some absorption of the product by the roots of plants growing in EcoS-treated substrate. However, another, and perhaps more logical, explanation for the differences noted in fluorescence activity between treated and untreated seedlings might be found in the observation that HydES-treated seedlings appeared less drought-stressed (less wilted) at harvest than did either the untreated or EcoS-treated seedlings, an explanation supported in part by gas exchange and xylem water potential data reported below. No significant differences in chlorophyll fluorescence were observed between the two species (red maple and river birch, both of which are fine-rooted), or between the two production types (PPS- and BRS-grown maples) used in these trials (Table 3).

Chlorophyll fluorescence has been widely used as a method for studying the mechanisms by which a range of environmental factors alter photosynthetic capacity (BolharNordenkampf el al. 1989). Using chlorophyll fluorescence, Richardson et al. (2004) found that maximum quantum efficiency was slightly higher in biostimulant-treated birch seedlings than in similar seedlings receiving no biostimulant. Fraser and Percival (2003) reported finding a significant increase in tree vitality (assessed using a performance index based on chlorophyll fluorescence emissions) in fouryear-old biostimulant-treated oak, birch, and beech seedlings. While the effects of biostimulant treatment reported in the aforementioned studies may have been triggered by one or more of the active ingredients found in these products (e.g., ascorbic acid, casein hydrolysate, myo-inositol, etc.), this seems less likely the case in the present study, although the extremely high surfactant concentration found in EcoS could potentially impact physiological activity.

\section{Leaf Gas Exchange}

Measurements of net Pn recorded for groups of three droughtstressed seedlings (one untreated, one HydES-treated, one EcoS-treated) at the point when each untreated seedling first wilted, showed that Pn for PPS maples grown in HydES-treated media $\left(2.8 \mu \mathrm{mol} / \mathrm{m}^{2} / \mathrm{s}\right)$ was almost three times greater than for untreated maples $\left(0.97 \mu \mathrm{mol} / \mathrm{m}^{2} / \mathrm{s}\right)$ and more than five times greater than for similar maples grown in EcoS-treated media $\left(0.5 \mu \mathrm{mol} / \mathrm{m}^{2} / \mathrm{s}\right)$ (Table 4). These observations suggest that, at harvest, the level of water stress in HydES-treated maples was probably lower than it was in either EcoS-treated or untreated maples, thereby allowing the stomates of HydES-treated seedlings to remain open for longer periods of time, and permitting a greater exchange of $\mathrm{CO}_{2}$ and water vapor between the leaf and the atmosphere. Ts and $r_{s}$ measurements, although not statistically different, lend support to this supposition (Table 4); however, time-course studies would be required to prove or disprove this assumption. No significant differences in leaf gas exchange were found between the two species (red maple and river birch, both fine-rooted) or between the two production types (PPS and BRS red maples) included in these trials (Table 3).

The results of this investigation confirmed earlier results reported by Ferrini and Nicese (2002), who found an increase in both net photosynthesis and evaporation rate in biostimulanttreated Quercus robur L. (English oak), and by Richardson et al. (2004) who reported finding marginally higher rates of photosynthesis in biostimulant-treated paper birch. In contrast, Sammons and Struve $(2004 ; 2005)$ found reduced short term transpirational water use in container-grown Quercus rubra L. (red oak) and fieldgrown Koelreuteria paniculata Laxm. (goldenrain tree) treated with a biostimulant intended to reduce stress. Dissimilarities in the above mentioned studies may have resulted from differences in the active ingredients contained in each of the various biostimulant products used, some of which may have an effect on hydraulic conductivity in the xylem (Berlyn and Sivaramakrishnan 1996).

Table 4. Physiological activity of one-year-old, drought-stressed tree seedlings treated with Hydretain ES (HydES) and EcoSential $(\text { EcoS) })^{2}$.

\begin{tabular}{|c|c|c|c|c|c|c|c|c|}
\hline Species & $\begin{array}{l}\text { Production } \\
\text { type }\end{array}$ & Humectant & $\mathrm{Fv} / \mathrm{Fm}^{\mathrm{x}}$ & $\phi$ PSII $^{w}$ & $\begin{array}{l}\operatorname{Pn}^{v} \\
\left(\mu \mathrm{mol} / \mathrm{m}^{2} / \mathrm{s}\right)\end{array}$ & $\begin{array}{l}\mathrm{Ts}^{\mathrm{u}} \\
\left(\mathrm{mol} / \mathrm{m}^{2} / \mathrm{s}\right)\end{array}$ & $\begin{array}{l}\mathrm{r}_{\mathrm{s}}^{\mathrm{t}} \\
\left(\mathrm{m}^{2} / \mathrm{s} / \mathrm{mol}\right)\end{array}$ & $\begin{array}{l}\text { XWPs } \\
(\mathrm{MPa})\end{array}$ \\
\hline \multirow{5}{*}{$\begin{array}{l}\text { Red } \\
\text { maple }\end{array}$} & \multirow[t]{2}{*}{ PPS } & 0 (control) & $0.774 a$ & $0.077 \mathrm{~ns}$ & $0.97 \mathrm{ab}$ & $0.20 \mathrm{~ns}$ & $122.0 \mathrm{~ns}$ & $-2.57 \mathrm{a}$ \\
\hline & & HydES & $0.785 a$ & 0.070 & $2.80 \mathrm{a}$ & 0.41 & 102.7 & $-1.17 b$ \\
\hline & \multirow[t]{3}{*}{ BRS } & 0 (control) & $0.675 n s$ & $0.083 \mathrm{~ns}$ & $0.25 \mathrm{~ns}$ & $0.09 \mathrm{~ns}$ & $213.8 \mathrm{a}$ & $-3.74 a$ \\
\hline & & HydES & 0.756 & 0.128 & 1.27 & 0.24 & $81.6 b$ & $-1.77 b$ \\
\hline & & EcoS & 0.724 & 0.070 & 0.95 & 0.19 & $105.4 \mathrm{~b}$ & $-2.28 \mathrm{ab}$ \\
\hline \multirow{2}{*}{$\begin{array}{l}\text { River } \\
\text { birch }\end{array}$} & \multirow[t]{2}{*}{ BRS } & 0 (control) & $0.724 \mathrm{~ns}$ & $0.104 \mathrm{~ns}$ & $0.50 \mathrm{~ns}$ & $0.05 \mathrm{~ns}$ & $295.1 \mathrm{~ns}$ & $-1.53 \mathrm{~ns}$ \\
\hline & & EcoS & 0.752 & 0.056 & 1.01 & 0.13 & 168.2 & -1.72 \\
\hline
\end{tabular}

${ }^{\mathrm{z}}$ Seedlings grown in a greenhouse in $3.8 \mathrm{~L}$ plastic pots filled with soilless substrate (Metromix 560) and treated with $16 \mathrm{~mL} / \mathrm{L}$ HydES or EcoS prior to withholding water. Each value represents the mean of six replications. For each species and production type, values in the same column differ significantly when followed by a different letter, Tukey $0.05 ; \mathrm{ns}=$ no significant differences.

y Peat plug-grown (PPS) seedlings; bare root-grown (BRS) seedlings.

${ }^{x}$ Variable/maximum fluorescence (max efficiency of PSII photochemistry).

w Quantum yield of PSII.

v Photosynthetic rate.

"Transpiration rate

${ }^{t}$ Stomatal resistance.

${ }^{\mathrm{s}}$ Xylem water potential. 


\section{Xylem Water Potential}

Based on the leaf gas exchange measurements reported, it was not unexpected that xylem water potential $\left(\Psi_{\mathrm{x}}\right)$ in droughted, HydES-treated red maples (which averaged -1.47 MPa for both PPS- and BRS-grown seedlings) was higher (less negative) than it was in droughted, EcoS-treated seedlings (which averaged -2.14 MPa across both production types) (Table 4). And, while seedlings of both species had higher (less negative) water potentials when grown in humectant-treated substrate, only those grown in HydES-treated media were significantly higher than the untreated controls (Table 4). In comparing xylem water potential measurements between species (red maple versus river birch) and between production types (PPS versus BRS maples), no significant treatment differences were observed (Table 3).

From the results of these studies with HydES and EcoS, the following conclusions were drawn: 1) the moisture content of humectant-treated substrate was consistently higher throughout a progressive drying cycle than it was in untreated substrate; 2) foliar growth was unaffected by humectant treatment, but fine root growth was less extensive for seedlings grown in humectanttreated substrate, a finding attributed to more available soil moisture in the treated media; 3) plant-water stress was lower in humectant-treated maples than it was in untreated (control) plants, and physiological activity (fluorescence and net photosynthesis) was consistently higher in both HydES-treated and untreated seedlings than it was in EcoS-treated plants; 4) for the species included in these studies, root growth of humectant-treated red maple (fine-rooted) outperformed root growth of humectant-treated yellow poplar (coarse-rooted); 5) between the two production types, root growth of bare-root seedlings was generally greater than the root growth of peat plug seedlings of the same species.

Acknowledgments. This project was carried out with financial support from the TREE Fund's Hyland Johns research grant program (06-HJ-06).

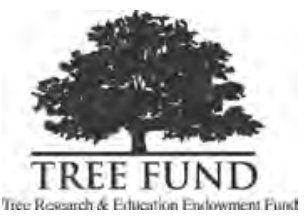

\section{LITERATURE CITED}

Abbey, T., and T. Rathier. 2005. Effects of mycorrhizal fungi, biostimulants and water absorbing polymers on the growth and survival of four landscape plant species. Journal of Environmental Horticulture 23:108-111.

Arena, M.J. 2001. Evaluation of Hydretain 2X on container grown trees. Clemson Univ. Extension Service. <www.hydretain.com/literature/ container_grown_trees.pdf>

Barrett, J. 1991. New media-applied humectant can improve plants' drought resistance. Greenhouse Manager 10:123.

Berlyn, G.P., and S. Sivaramakrishnan. 1996. The use of organic biostimulants to reduce fertilizer use, increase stress resistance, and promote growth, pp. 106-112. In: T.D. Landis and D.B. South (Eds.). National Proceedings, 1996 Forest and Conservation Nursery Association Meeting. Gen. Tech. Rep. PNW-GTR-389. Dept. of Agriculture, Forest Service, Pacific Northwest Research Station, Portland, OR.

Bolhar-Nordenkampf, H.R., S.P. Long, N.R. Baker, G. Oquist, U. Schreiber, and E.G. Lechner. 1989. Chlorophyll fluorescence as a probe of the photosynthetic competence of leaves in the field: A review of current instrumentation. Functional Ecology 3:497-514.
Ciardi, J.A., C.S. Vavrina, and M.D. Orzolek. 1998. Evaluation of tomato transplant production methods for improving establishment rates. HortScience 33:229-232.

Ferrini F., and F.P. Nicese. 2002. Response of English oak (Quercus robur $\mathrm{L}$.) trees to biostimulants application in the urban environment. Journal of Arboriculture 28:70-75.

Fraser, G.A., and G.C. Percival. 2003. The influence of biostimulants on growth and vitality of three urban tree species following transplanting. Arboricultural Journal 27:43-57.

Hanson, R.P. 1999. Solution for plant root watering. United States patent $5,865,869$.

Hasse D.L., and R. Rose. 1993. Soil moisture stress induces transplant shock in stored and unstored 2+0 Douglas-fir seedlings of varying root volumes. Forest Science 39:275-294.

Jupp, A.P., and E.I. Newman. 1987. Morphological and anatomical effects of severe drought on roots of Lolium perenne L. New Phytologist 105:393-402.

Kramer, P.J., and J.S. Boyer. 1995. Water Relations of Plants and Soils. Academic Press, New York City, New York, U.S.

Larson, P.R., and J.G. Isebrands. 1971. The plastochron index as applied to developmental studies of cottonwood. Canadian Journal of Forest Research 1:1-11.

Marzouk, H., P. Baur, and J. Schonherr. 1998. Relative solubilities of bifenox and 1-naphthylacetic acid (NAA) in plant cuticles and in selected pure or aqueous glycol additives. Pesticide Science 53:278-284.

Matsumoto, S., S. Suzuki, H. Tomita, and T. Shigematsu. 1992. Effects of humectants on pesticide uptake through plant leaf surfaces, pp. 261271. In: C.L. Foy (Ed.). Adjuvants for Agrichemicals. CRC Press, Boca Raton, Florida, U.S.

Maxwell, K., and G.N. Johnson. 2000. Chlorophyll fluorescence - a practical guide. Journal of Experimental Botany 51:659-668.

Monterusso, M.A., D.B. Rowe, and C.L. Rugh. 2005. Establishment and persistence of Sedum spp. and native taxa for green roof applications. HortScience 40:391-396.

Ramsey, R.J.L., G.R. Stephenson, and J.C. Hall. 2005. A review of the effects of humidity, humectants and surfactant composition on the absorption and efficacy of highly water-soluble herbicides. Pesticide Biochemistry and Physiology 82:162-175.

Ramsey, R.J.L., G.R. Stephenson, and J.C. Hull. 2006. Effects of humectants on the uptake and efficiency of glufosinate in wild oat (Avena fatua) plants and isolated cuticles under dry conditions. Weed Science 54:205-211.

Richardson, A.D., M. Aikens, G.P. Berlyn, and P. Marshall. 2004. Drought stress and paper birch (Betula papyrifera) seedlings: Effects of an organic biostimulant on plant health and stress tolerance, and detection of stress effects with instrument-based, noninvasive methods. Journal of Arboriculture 30:52-60.

Roberts, B.R. 2006. Compost-containing substrates and their effect on post-transplant growth of containerized tree seedlings. Arboriculture \& Urban Forestry 32:289-296.

Roberts, B.R., and R.S. Linder. 2010. Humectants as post-plant soil amendments: Effects on the wilting cycle of drought-stressed, container-grown tree seedlings. Arboriculture \& Urban Forestry 36:275-280.

Ruan, X., D. Li, Q. Xu, H. Mao, G. Li, Y. Gong, T. Kuang, and N. Zhao. 2002. Phosphatidylcholine-induced reactivation of photosystem II membranes penetrated with Triton X-100. Journal of Photochemistry and Photobiology B: Biology 87:109-115.

Sagaram, M., and J.K. Burns. 2009. Leaf chlorophyll fluorescence parameters and Huanglongbing. Journal of the American Society for Horticultural Science 134:194-201. 
Sammons, J.D. and D.K. Struve. 2004. Effect of Bioplex ${ }^{\mathrm{TM}}$ on transplant success of non-dormant red oak (Quercus rubra L.). Journal of Environmental Horticulture 22:197-201.

Sammons, J.D. and D.K. Struve. 2005. Effect of Bioplex ${ }^{\mathrm{TM}}$ on transplant success and recovery of summer-dug goldenraintree. Journal of Environmental Horticulture 23:59-62.

Sharp, R.E., and W.J. Davies. 1979. Solute regulation and growth by roots and shoots of water-stressed maize plants. Planta 147:43-49.

Struve, D.K. 2009. Tree establishment: A review of some of the factors affecting transplant survival and establishment. Arboriculture and Urban Forestry 35:10-13.

Watson, G.W., and E.B. Himelick. 1997. Principles and Practice of Planting Trees and Shrubs. International Society of Arboriculture, Savoy, IL. 199 pp.

Wiseman, E. 2004. Water stress in trees. Arborists News (December):13-14.

Bruce R. Roberts (corresponding author)

Dept. of Botany \& Microbiology

Ohio Wesleyan University

Delaware, OH 43015, U.S.

broberts@owu.edu

\section{R. Scott Linder}

Dept. of Mathematics and Computer Science

Ohio Wesleyan University

Delaware, OH 43015, U.S.

Charles R. Krause

Application Technology Research Unit

USDA, ARS, MWA

Wooster, OH 44691, U.S.

\section{Ryan Harmanis}

Dept. of Mathematics and Computer Science

Ohio Wesleyan University

Delaware, $\mathrm{OH} 43015$, U.S.

Résumé. Des semis d'un an d'érable rouge (Acer rubrum L.) et de tulipier (Liriodendron tulipifera L.) ont été traités avec de le Hydretain ES $^{\text {TM }}$ (HydES) ou de l'EcoSential ${ }^{\mathrm{TM}}$ (EcoS) par application sur le sol. Un cycle progressif d'assèchement a été imposé après le traitement et, lorsque que les feuilles de chaque semis se sont flétries, les feuilles et les racines ont été récoltées. La croissance foliaire n'a pas été affectée par le HydES ou l'EcoS, mais la croissance des racines (racines $<1 \mathrm{~mm}$ en diamètre) a été significativement moindre pour les semis cultivés dans le substrat traité par humectation. Ces données, en combinaison avec des mesures de contenu en humidité du substrat prises durant un cycle similaire de sécheresse, suggèrent que la croissance en fines radicelles induite par la sécheresse dans un substrat traité par humectation était ralentie parce qu'il y avait moins de besoins pour ces racines de s'allonger et de proliférer afin de rechercher un apport supplémentaire d'humidité dans le sol. Dans des études menées l'année suivante, le HydES et l'EcoS ont été appliqués sur le sol avec des semis d'un an d'érable rouge et de bouleau noir (Betula nigra L.) avant de diminuer l'irrigation. Dans ces études, des mesures de fluorescence en chlorophylle, d'échanges gazeux foliaires et de potentiel en eau du xylème ont indiquées que l'activité physiologique était plus élevée pour les semis soumis à un stress hydrique qui poussaient dans un substrat traité avec le HydES comparativement à des semis similaires dans un substrat qui avait été traité avec l'EcoS, une situation attribuable à des niveaux plus faibles de stress en eau chez la plante (potentiel en eau du xylème plus élevé) chez les semis traités avec le HydES.
Zusammenfassung. Einjährige Sämlinge von Rotahorn und Tulpenbaum wurden mit Hydretain ES ${ }^{\mathrm{TM}}$ (HydES) oder EcoSential ${ }^{\mathrm{TM}}$ (EcoS) als Bodenauftrag behandelt. Nach der Behandlung wurde eine progressive Trockenperiode eingeleitet und als die Sämlinge welkten, wurden Wurzeln und Blätter geerntet. Das Wachstum der Blätter wurde durch HydES oder EcoS nicht beeinflusst, aber das Wurzelwachstum (Wurzeln $<1 \mathrm{~mm}$ Durchm.) war bei den Sämlingen in den mit Feuchthaltemitteln behandelten Substraten deutlich geringer. Diese Data zusammen mit den Messungen zum Feuchtegehalt des Substrats während einer ähnlich trockenen Periode ergeben, dass das durch Trockenheit beeinflusste Wachstum von Feinwurzeln in den mit Feuchthaltemitteln behandelten Substraten langsamer ist, weil für diese Wurzeln weniger Anreiz zum Wachsen und Ausdehnen besteht, um sich weitere Feuchtigkeitsquellen zu erschließen. In den Studien des Folgejahres wurde HydES oder EcoS wieder als Bodenapplikation auf einjährige Sämlinge von Rotahorn und Schwarzbirke appliziert bevor die Trockenperiode eingeleitet wurde. In dieser Studie zeigten die Messungen von Blattchlorophyll-Fluoreszenz, Blattgasaustausch und Xylem-Wasserpotential, dass die physiologische Aktivität bei trockenheitsgestressten Sämlingen in mit HydES behandelten Substraten, verglichen mit ähnlichen Sämlingen in mit EcoS behandelten Substraten, größer war, ein Zustand, der dem niedrigeren Level von Blattwasser-Stress (Xylem-Wasserpotential) in den mit HydES behandelten Sämlingen zugeschrieben wird.

Resumen. Brinzales de un año de maple rojo (Acer rubrum L.) y poplar amarillo (Liriodendron tulipifera L.) fueron tratados con Hydretain ES ${ }^{\text {TM }}$ (HydES) o EcoSential ${ }^{\text {TM }}$ (EcoS) aplicados al suelo. Se impuso un ciclo de sequía progresiva después del tratamiento y a medida que cada brinzal se marchitó las hojas y las raíces fueron cosechadas. El crecimiento foliar no fue afectado por HydES o EcoS, pero el crecimiento de las raíces (raíces $<1 \mathrm{~mm}$ de diámetro) fue significativamente menor para el crecimiento de los brinzales en el tratamiento humectante. Estos datos, al igual que las mediciones del contenido de humedad del sustrato tomados durante un período similar de sequía, sugiere que en la sequía-inducida el crecimiento de raíces finas en el medio humectante fue más lento debido a que hubo necesidad para estas raíces de extenderse y proliferar en busca de aportes de humedad adicional del suelo. En estudios conducidos el año siguiente, HydES o EcoS fueron aplicados en zanjas al suelo a los brinzales de un año de maple rojo y betula de río (Betula nigra L.) antes de la retención del riego. En estos estudios, las mediciones de clorofila fluorescente, intercambio de gases foliares y potencial hídrico en el xilema indica que la actividad fisiológica fue mayor para los brinzales estresados por sequía, creciendo en medio tratado con HydES, comparando con brinzales similares, creciendo en medio tratado con EcoS, una condición atribuida a los bajos niveles de estrés hídrico en la planta (potenciales hídricos del xilema más altos) en los brinzales tratados con HydES. 